\title{
Synthesis, Characterization, Antimicrobial Activity and Molecular Docking Studies of New Benzimidazole, Benzoxazole, Imidazole and Tetrazole Derivatives
}

\author{
SUBRAMANIYAN ARULMURUGAN ${ }^{1}$ and HELEN P. KAVITHA ${ }^{1 *}$ \\ 'Department of Chemistry, SRM Institute of Science and Technology, Ramapuram Campus, \\ Chennai-600089, Tamil Nadu, India. \\ ${ }^{*}$ Corresponding author E-mail: helenkavithap2020@gmail.com \\ http://dx.doi.org/10.13005/ojc/360411
}

(Received: July 20, 2020; Accepted: August 21, 2020)

\begin{abstract}
In the present research work, 12 new compounds, such as benzimidazole (3, 3a-c), benzoxazole(4), imidazole (5, 5a-c) and tetrazole (6, 6a-c) were synthesized. FT-IR, Proton NMR (1H), ${ }^{13} \mathrm{C}-\mathrm{NMR}$, Mass spectral values were used to prove the structures of the compounds. The antimicrobial potential of the representative compounds was assessed using the Disc diffusion process. All the benzoxazole, benzimidazole, imidazole and tetrazole derivatives prepared in this investigation show good antimicrobial activity. However the antimicrobial activities of the compounds are less compared with standard drugs. Molecular docking studies have also done for the synthesized compounds all the compounds show hydrogen bond interactions with receptor protein.
\end{abstract}

Keywords: Benzoxazole, Benzimidazole, Imidazole, Tetrazole, Antimicrobial activity, Molecular docking

\section{INTRODUCTION}

The present situation is that the incidence of multidrug-resistant bacterial infections and physicians has become dependent on vancomycin is an antibiotic used to treat a number of complicated infections that are immune to conventional agents, suggesting that new groups of antimicrobials need to be created ${ }^{1}$. Subsequently, antimicrobial agents whose chemical properties vary fully from those current agents need to be built up and can replace the resistance problem ${ }^{2}$.
Benzimidazole based compounds are of broad area of interest as a result of their various biological activities like antimicrobial activity ${ }^{3}$, antioxidant activity ${ }^{4}$, anticancer activity ${ }^{5}$, antidiabetic activity $^{6}$, antiviral activity ${ }^{7}$, anticonvulsant activity ${ }^{8}$ etc.

Benzoxazole is one of the main heterocyclic compounds that are very useful in the area of medicine. Among other medicinal compounds it has been used, making it a convertible heterocyclic compound with an extensive variety of biological activities, such as antimicrobial activity ${ }^{9}$, antiinflammatory activity ${ }^{10}$, anticancer activity ${ }^{11}$, aminopeptidase activity ${ }^{12}$, anti$\mathrm{HIV}^{13}$ etc.

This is an Open Access article licensed under a Creative Commons license: Attribution 4.0 International (CC- BY). Published by Oriental Scientific Publishing Company @ 2018 
Imidazole is standard five-membered heterocyclic scaffolds containing nitrogen, and is commonly found in natural products and medicinal molecules. In addition, heterocyclic imidazolebased compounds possessing various biological activities, such as antibacterials ${ }^{14}$, antifungal ${ }^{15}$, antiinflammatory ${ }^{16}$, antiviral ${ }^{17}$, anti-parasitic ${ }^{18}$, anticancer ${ }^{19}$, antihistaminic ${ }^{20}$, and enzyme inhibition ${ }^{21}$.

In recent decades, the synthesis of tetrazoles and the study of their chemical and biological behavior have become more important in the biological and pharmaceutical fields such as antibacterial ${ }^{22}$, antifungal ${ }^{23}$, anticancer ${ }^{24}$, antiinflammatory ${ }^{25}$ and analgesic ${ }^{26}$ activities. In the above-mentioned facts it was anticipated that, when mixed together, these active pharmacophores would produce novel molecular compounds that are likely to exhibit fascinating biological properties. Subsequently, continuation of our attention to the synthesis of biologically active heterocycles ${ }^{27}$, we have reported some new heterocyclic compounds like benzimidazole, benzoxazole, imidazole and tetrazole derivatives synthesis and antimicrobial evaluation.
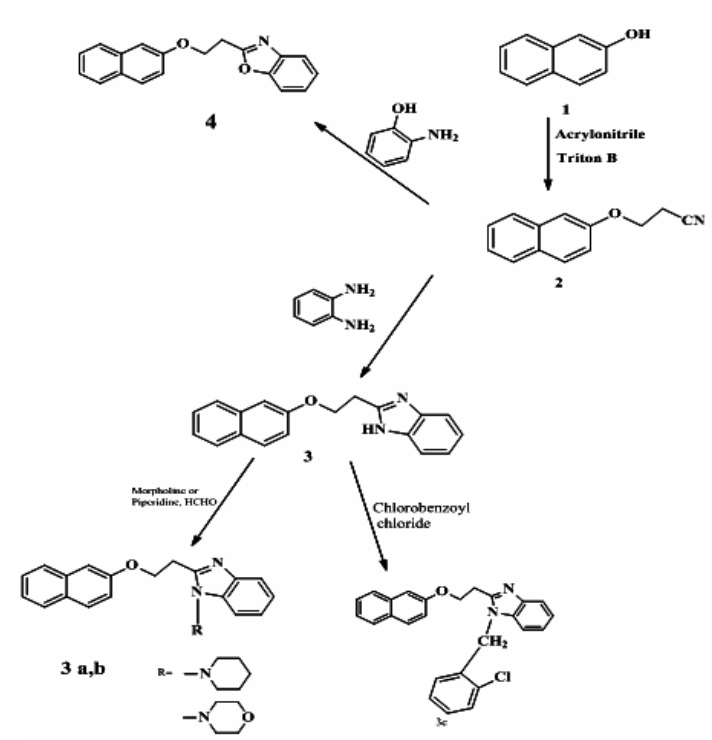
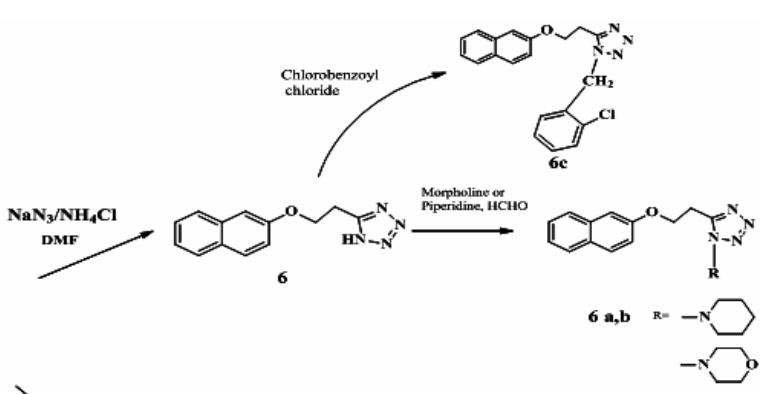

$\underset{\mathrm{H}_{2} \mathrm{C}-\mathrm{NH}_{3}}{\mathrm{H}_{2} \mathrm{C}-\mathrm{NH}_{2}}$
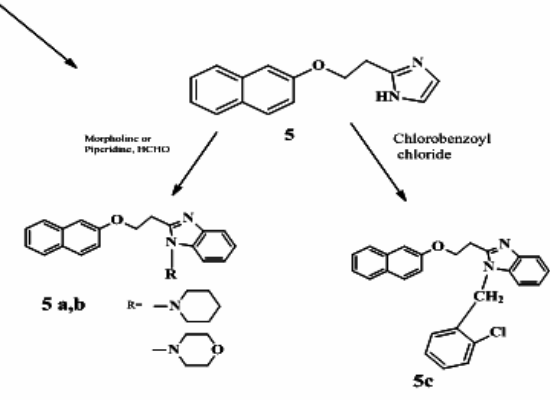

Scheme 1. Synthetic route of benzimidazole, benzoxazole, imidazole and tetrazole derivatives

\section{Experimental Techniques}

Infrared spectra were taken on the Perkin-

Elmer FT-IR 1600 spectrometer using potassium bromide disks. NMR spectra were recorded by Bruker spectrometer at $500 \mathrm{MHz}$ and $125 \mathrm{MHz}$ for ${ }^{13} \mathrm{C}$ spectra. Melting points have analyzed by a digital melting point apparatus. The reactions were monitored by TLC using solvent systems of different polarities. Mass spectra recorded by JEOL GCmate spectrometer.

\section{Synthesis of heterocyclic compounds}

Synthesis of heterocyclic compounds, such as $\mathbf{3}, \mathbf{4}, \mathbf{5}, \mathbf{6}$ were prepared according to the reported procedure ${ }^{27}$. Synthesis of $\mathbf{3 a}, \mathbf{3 b}, \mathbf{5} \mathbf{a}, \mathbf{5} \mathbf{b}$, $6 \mathbf{a}, \mathbf{6 b}$ were synthesis using reported procedure ${ }^{28}$ and the synthesis of $\mathbf{3 c}, \mathbf{5 c}, \mathbf{6 c}$ derivatives were

prepared according to reported procedure ${ }^{29}$.

\section{Determination of Antimicrobial Study}

Antimicrobial properties of the samples were screened against bacteria's, such as $S$. aureus, $P$. aeruginosa, and $B$. subtilis and fungi, such as $C$. albicans and $A$. niger by Disc Diffusion method. Muller Hinton agar media and PDA (Potato Dextrose Agar) used antibacterial and antifungal studies to subculture different strains of microorganisms, respectively.

\section{Molecular docking tools}

Docking studies were performed for synthesized compounds according to the reported procedure $^{30}$ with target proteins by Glide 5.5 module of Schrodinger suite. 
KAVITHA, ARULMURUGAN., Orient. J. Chem., Vol. 36(4), 672-679 (2020)

Table 1: Melting Point and Yield of the synthesized compounds

\begin{tabular}{|c|c|c|c|}
\hline Compound & Compound Structure and name & $\mathrm{m} \cdot \mathrm{p}\left({ }^{\circ} \mathrm{C}\right)$ & Yeild (\%) \\
\hline 3 & & 72 & 62 \\
\hline $3 a$ & & 57 & 71 \\
\hline $3 b$ & & 78 & 68 \\
\hline $3 c$ & & 58 & 70 \\
\hline 4 & & 73 & 63 \\
\hline 5 & & 77 & 85 \\
\hline $5 a$ & & 74 & 80 \\
\hline $5 b$ & & 68 & 76 \\
\hline $5 c$ & & 54 & 68 \\
\hline 6 & & 50 & 62 \\
\hline $6 a$ & & 58 & 75 \\
\hline $6 b$ & & 53 & 71 \\
\hline $6 c$ & & 61 & 70 \\
\hline
\end{tabular}




\section{RESULT AND DISCUSSION}

\section{Antimicrobial Activity}

The antimicrobial evaluation of the representative samples was performed by Disc Diffusion Technique. The test bacteria's, such as $S$. aureus, B. subtilis, P. valgaris and $K$. aerogenes

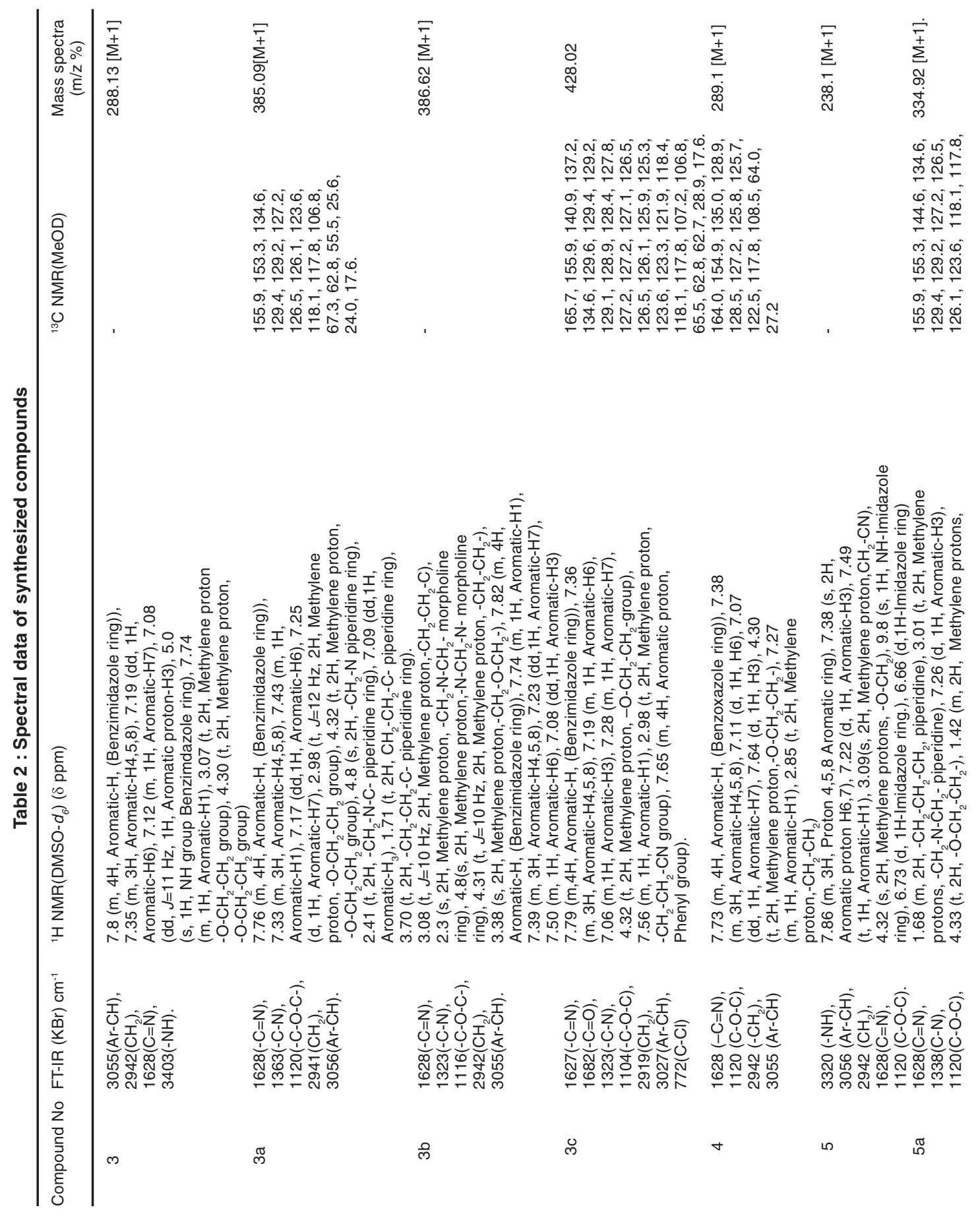

as well as fungi, such as $A$. niger and $C$. albicans. Test effect distinguished with positive control (Ciprofloxacin for bacteria; Nystatin for fungi). The values of zone of inhibitions are presented in the table (Table 3). The photographs showing the zone of inhibition against the tested species are given in the figures (Figure 1).

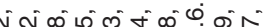
+

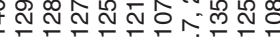

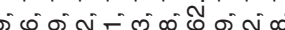

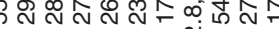
- 0 ๑่ 

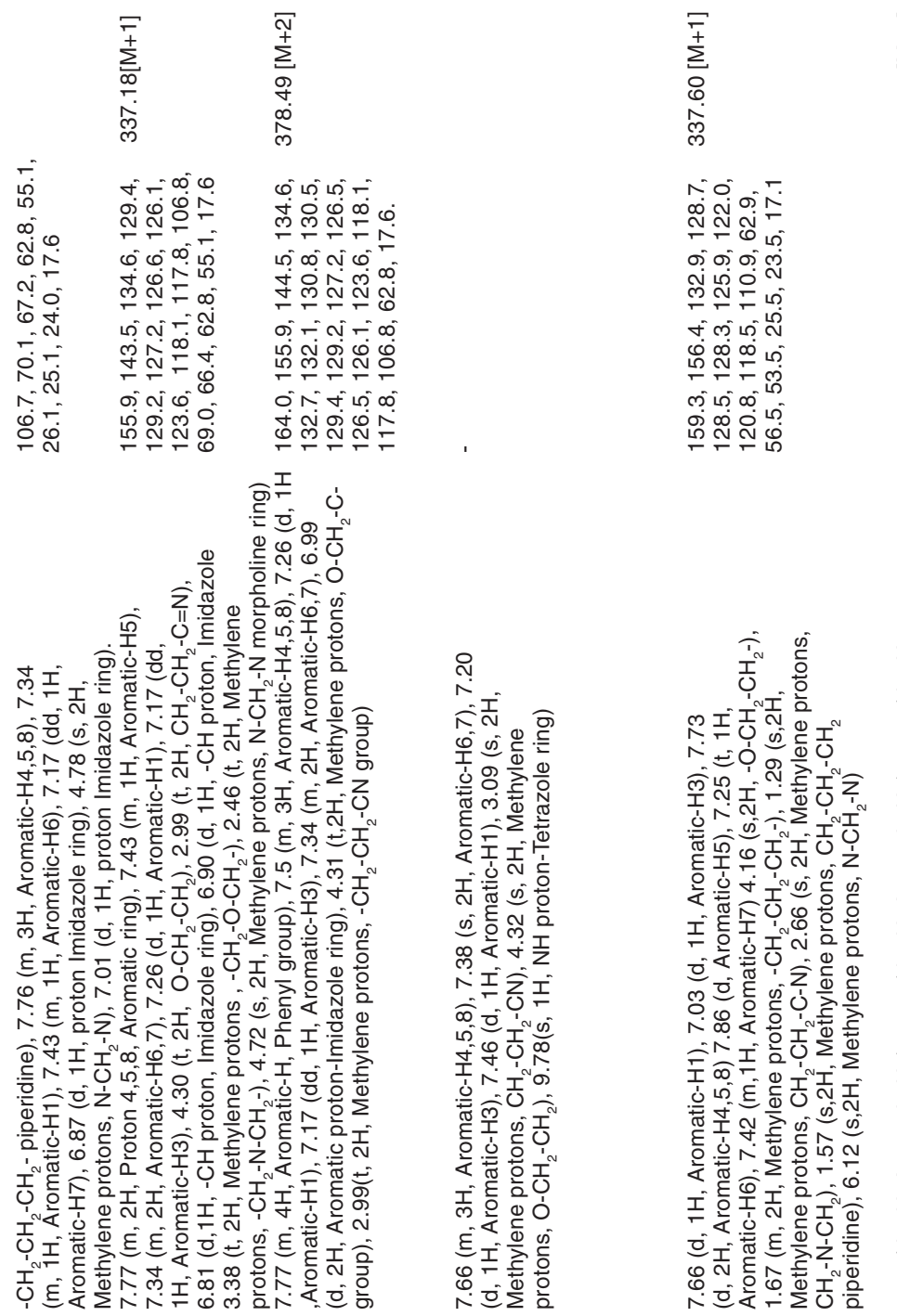

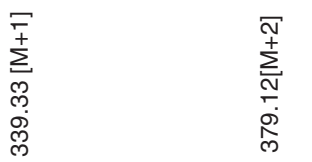

ベ๐

क०

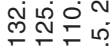

จ ले

官 $\stackrel{\infty}{\sim} \stackrel{\infty}{\leftarrow}$

ल

ํํㅁ원

के

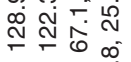

$\because \div$ กั่

लํํㄷㄴ

$\therefore$ ल ल

绝 㐫

एक

مึ

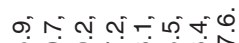

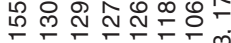

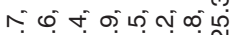

吕

$000=0$ - 0 -

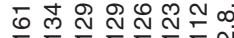

$=00=-100$

섬웜

\section{|}


using Schrodinger (Mastro 9.2 V) suite to learn the right binding site of the compounds. All the compounds from Scheme 1, which were tested for the antimicrobial activity were taken for the docking studies and molecular docking was performed against antimicrobial protein beta-ketoacyl-acp synthase III+ malonyl-COA (pdb id: 1HNJ). All the ligands interact with antimicrobial protein receptor. Glide Score, glide energy and hydrogen bond distance for the Compounds with protein are given in the Table 4.

Table 3: Antimicrobial study of the new compounds

\begin{tabular}{lccccccccc}
\hline \multirow{2}{*}{ S. No } & Microorganism & \multicolumn{7}{c}{ Zone of Inhibition (mm) } & \\
& & $3 a$ & $3 b$ & $5 b$ & $5 c$ & $6 a$ & $6 b$ & Solvent control & Std \\
& & & & & & & & & \\
& Staphyloccocus aureus & 18 & 20 & 15 & 10 & 14 & 19 & - & 35 \\
2 & Bacillus subtilis & 16 & 20 & 14 & 10 & 12 & 20 & - & 40 \\
3 & Proteus valgaris & 15 & 12 & 16 & 13 & 14 & 12 & - & 26 \\
4 & Klebseilla aerogenes & 16 & 16 & 20 & 12 & 16 & 18 & - & 30 \\
5 & Aspergillus niger & 18 & 20 & 20 & 18 & 16 & 18 & - & 35 \\
6 & Candida albicans & 21 & 20 & 24 & 20 & 20 & 21 & - & 32 \\
\hline
\end{tabular}

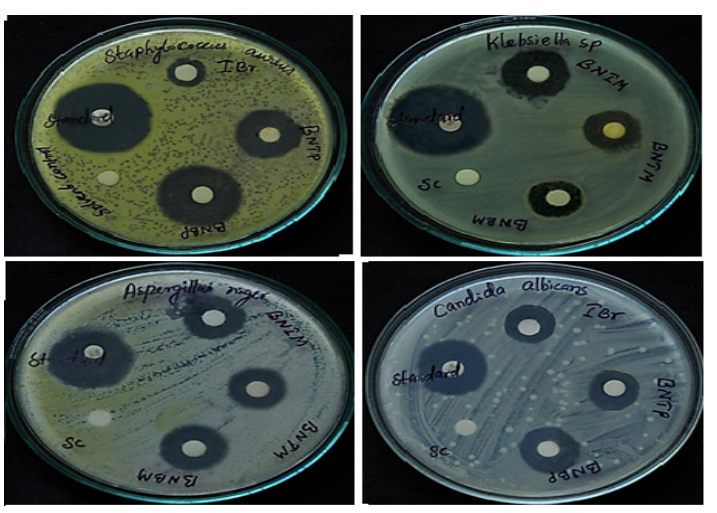

Fig.1. Antimicrobial activity of $3 a, 3 b, 5 b, 5 c, 6 a$ and $6 b$ denoted as BNBP, BNBM, BNIM, IBr, BNTP and BNTM against Staphyloccocus aureus, Klebseilla aerogenes, Aspergillus niger and Candida albicans
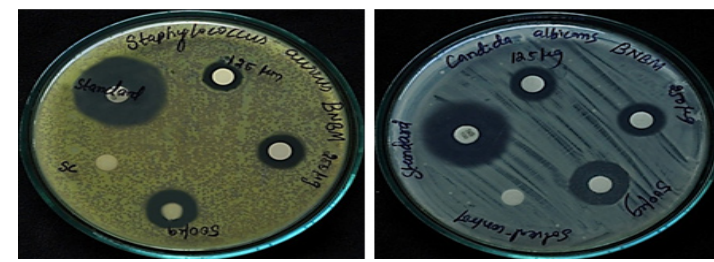

Fig. 2. Minimum Inhibitory Concentration of the compound $3 b$ against bacteria and fungi
Amino acid residue ARG36-NH of the enzyme beta-ketoacyl-acp synthase III is form hydrogen bond with the $\mathrm{O}$ atom of the ligand $3 \mathbf{b}$ (Fig. 3). Fig. 3 shows that the amino acid residues ARG249, PHE213 and TRP32 of the enzyme beta-ketoacyl-acp synthase III are involved in $\pi-\pi$ interaction with benzene of the benzimidazole ring and chlorobenzene ring of the ligand $3 \mathbf{c}$, and the ARG36-NH of the amino acid residue form hydrogen bond with compound $\mathbf{3 c}$.

Amino acid residue ASN247-NH of the enzyme beta-ketoacyl-acp synthase III is formation of hydrogen bond interaction with the $\mathrm{O}$ atom of 2-Napthol ring of the compound 4. The $\mathrm{N}$ atom of the Imidazole compound $5 \mathrm{a}$ is involved in hydrogen bond interaction with $\mathrm{O}$ atom of ASN247. Similarly the Nitrogen atom of Imidazole compound $\mathbf{5 b}$ is produced hydrogen bond interaction with $\mathrm{O}$ atom of ASN247. The $\mathrm{N}$ of tetrazole compound $6 \mathrm{a}$ is hydrogen bond with $\mathrm{O}$ atom of ASN247 amino acid residue. The amino acid residue ARG249-NH of the enzyme beta-ketoacyl-acp synthase is formed hydrogen bond interaction with $\mathrm{O}$ atom of the morpholine ring of the compound $\mathbf{6 b}$. The amino acid residues ARG49-O, PHE18-O, ARG36-N and TRP32-O of the enzyme beta-ketoacyl-acp synthase are involved in hydrogen bond interaction with $\mathrm{N}, \mathrm{N}, \mathrm{C}=\mathrm{O}$, benzene $(\pi-\pi)$ of ligand compound $\mathbf{6 c}$.

Table 4: Minimum inhibitory concentration of the new compounds

\begin{tabular}{|c|c|c|c|c|c|c|c|}
\hline \multirow[t]{2}{*}{ S. No } & \multirow[t]{2}{*}{ Microorganism } & \multicolumn{6}{|c|}{ Zone of Inhibition (mm) } \\
\hline & & Sample code & $125 \mu \mathrm{g} / \mathrm{ml}$ & $250 \mu \mathrm{g} / \mathrm{ml}$ & $500 \mu \mathrm{g} / \mathrm{ml}$ & Solvent control & Std \\
\hline 1 & Staphyloccocus aureus & $3 b$ & 14 & 16 & 22 & - & 35 \\
\hline \multirow[t]{2}{*}{2} & Bacillus subtilis & $3 b$ & 15 & 18 & 20 & - & 40 \\
\hline & & $6 b$ & 12 & 14 & 20 & - & 30 \\
\hline 3 & Klebseilla aerogenes & $5 b$ & 17 & 18 & 21 & - & 30 \\
\hline \multirow[t]{2}{*}{4} & Aspergillus niger & $3 b$ & 16 & 18 & 22 & - & 35 \\
\hline & & $5 b$ & 19 & 20 & 21 & - & \\
\hline \multirow[t]{6}{*}{5} & Candida albicans & $3 a$ & 12 & 16 & 20 & - & 32 \\
\hline & & $3 b$ & 18 & 18 & 21 & - & \\
\hline & & $5 b$ & 16 & 16 & 20 & - & \\
\hline & & $5 c$ & 18 & 19 & 20 & - & \\
\hline & & $6 a$ & 18 & 20 & 24 & - & \\
\hline & & $6 b$ & 16 & 20 & 20 & - & \\
\hline
\end{tabular}


Table 5: Glide Score, Glide Energy and Hydrogen Bond Distance for the Compounds with Protein beta-ketoacyl-acp synthase III+ malonyl-COA (pdb id: 1HNJ)

\begin{tabular}{|c|c|c|c|c|}
\hline \multirow[t]{2}{*}{ Compound code } & \multirow[t]{2}{*}{ Glide gscore } & \multirow[t]{2}{*}{ Glide energykcal/mole } & \multicolumn{2}{|c|}{ Hydrogen bond } \\
\hline & & & Donor & Acceptor \\
\hline $3 b$ & -6.44 & -38.71 & $\mathrm{NH}$ of $\mathrm{ARG} 36$ & O of (Morpholine ring) \\
\hline \multirow[t]{4}{*}{$3 c$} & -6.14 & -44.89 & O of carbonyl group & $\mathrm{NH}$ of $\mathrm{ARG} 36$ \\
\hline & & & Benzene ring & $\operatorname{ARG} 249(\pi-\pi)$ \\
\hline & & & & $\operatorname{PHE} 213(\pi-\pi)$ \\
\hline & & & & $\operatorname{TRP} 32(\pi-\pi)$ \\
\hline 4 & -6.79 & -37.40 & $\mathrm{NH}$ of $\mathrm{ASN} 247$ & O of 2 -Napthol \\
\hline $5 a$ & -6.59 & -37.38 & $\mathrm{~N}$ (Imidazole ring) & O of ASN247 \\
\hline $5 b$ & -6.33 & -39.01 & $\mathrm{~N}$ of Imidazole & O of ASN247 \\
\hline $6 a$ & -6.65 & -39.49 & $\mathrm{~N}$ (tetrazole ring) & O of ASN247 \\
\hline $6 b$ & -6.20 & -31.25 & NH ARG 249 & O of (Morpholine ring) \\
\hline \multirow[t]{4}{*}{$6 c$} & -6.47 & -37.20 & $\mathrm{~N}$ of Terazole ring & O of ARG 49 \\
\hline & & & $\mathrm{N}$ of Terazole ring & O of PHE18 \\
\hline & & & $\mathrm{NH}$ of $\mathrm{ARG} 36$ & $\mathrm{C}=\mathrm{O}$ of tetrazole derivatives \\
\hline & & & O of TRP-32 & $\mathrm{CH}$ of benzene ring \\
\hline
\end{tabular}
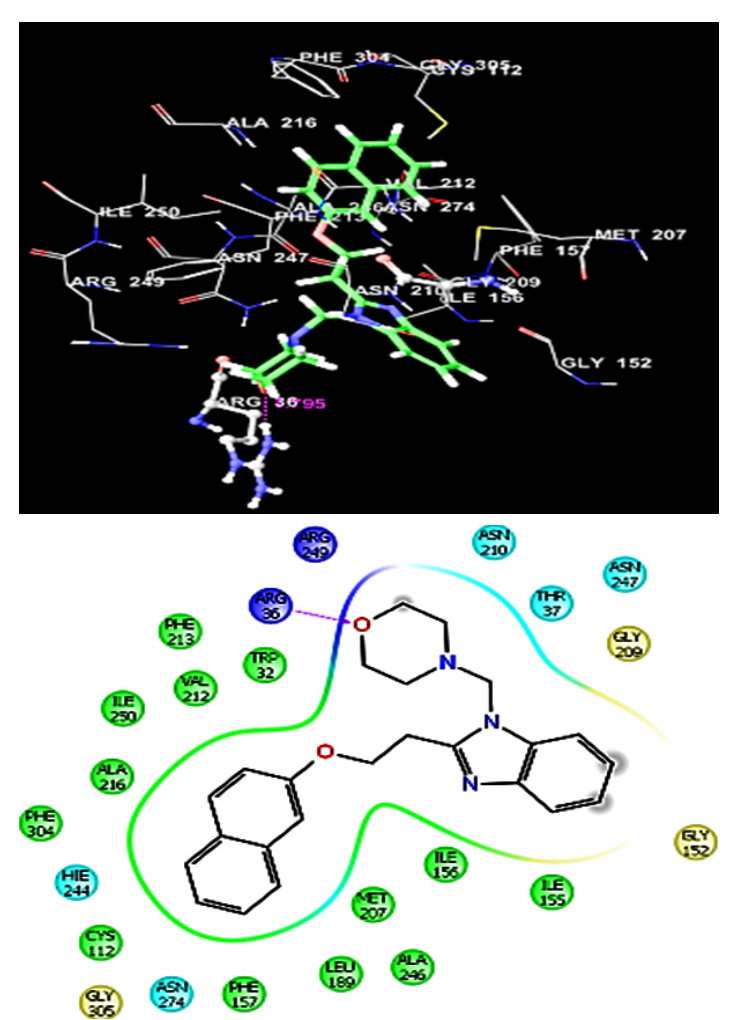

Fig. 3. Ligand interaction diagram of compound $3 \mathrm{~b}$ with the enzyme beta-ketoacyl-acp synthase III

\section{CONCLUSION}

In the current research work, 12 new heterocyclic compounds, such as benzimidazole, benzoxazole, imidazole and tetrazole derivatives were synthesized from 2-Napthol. In the expected region, the FT-IR spectra of newly synthesized derivatives showed absorption bands. The ${ }^{1} \mathrm{H}-\mathrm{NMR}$ and ${ }^{13} \mathrm{C}$-NMR spectra provided believable proof for the structure assigned to the synthesized compounds. Complete proof was obtained for the structures by getting the mass spectrum that reveal molecular ion peak equivalent to the molecular weight. Some of the representative compounds have been tested for antibacterial study against bacteria, such as $S$. aureus, B. subtilis, $P$. vulgaris and $K$. aerogenes by disc diffusion method. The antifungal property of the compounds was tested against $C$. albicans and $A$. niger. The outcome of the antimicrobial study indicates that the tested compounds showed reasonable to good antimicrobial property. However, the activity of the compounds is less than the standard drug. The Molecular Docking study was carried out using Schrodinger (Maestro 9.2v) software. The compounds were screened for the in vitro antibacterial study was screened in silico study against the antimicrobial protein enzyme beta-ketoacyl-acp synthase III. The findings of the analysis suggest that the compounds we used for docking exhibited interactions between the hydrogen bonds.

\section{ACKNOWLEDGMENT}

The authors are very much grateful for the moral support and encouragement offered by the management of the SRM Institute of Science and Technology, Ramapuram Campus.

\section{Conflict of interest}

No conflict of interest. 


\section{REFERENCES}

1. Chilumula, N. R.; Gudipati, R.; Ampati, S.; Manda, S.; Gadhe, D. Int. J .Chem. Res., 2010, 1, 1-6.

2. Dawood, N.T. A J.Chem. Pharm. Res., 2011, 3, 111-121.

3. Kumar, B. V.; Vaidya, S. D.; Kumar, R. V.; Bhirud, S. B.; Mane, R. B. Eur J Med Chem., 2006, 41, 599-604.

4. Kus, C.; Kilcigil, G. A.; Eke, B .C. Arch Pharm Res., 2004, 27, 156-163.

5. Kawasaki, K.; Masubachi, M.; Morikami, K.; Sogebe, S.; Aoyama, T.; Ebiike, H.; Niizuma, S.; Hayase, M.; Fujii, T.; Sakata, K.; Shindoh, H.; Shiratori, Y.; Aoki, Y.; Ohtsuka, T.; Shimma, N. Bioorg. Med. Chem. Lett., 2003, 13, 87-91.

6. Bathini, P.; Kameshwari, L.; Vijaya, N. Int. J. Basic. Clin. Pharmacol., 2013, 2, 814-818

7. Fonseca, T.; Gigante, B.; Marques, M.M.; Gilchrist, T.L.; Clercq, E.D. Bioorg. Med. Chem., 2004, 12, 103-112.

8. Falco, J.L.; Pique, M.; Gonzalez, M.; Buira, I.; Mendez, E.; Terencio, J.; Perez, C.; Princep, M.; Palomer, A.; Guglietta, A. Eur. J. Med. Chem., 2006, 41, 985-990.

9. Arpaci, O.T.; Oren, I.; Altanlar, N. I/ Farmaco., 2002, 57, 175-181.

10. Ampati, S.; Jukanti, R.; Sagar, V.; Ganta, R.; Manda, S. Der Chemica Sinica., 2010, 1, 157-168.

11. McKee, M. L.; Kerwin, S. M. Bioorg. Med. Chem., 2008, 16, 1775-1783.

12. Cellier, M.; Fabrega, O.J.; Fazackerley, E.; James, A.L.; Orenga, S.; Perry, J.D.; Salwatura, V. L.; Stanforth, S. P. Bioorg. Med. Chem., 2011, 19, 2903-2910.

13. Medebielle, M.; Ait-Mohand, S.; Burkhloder, C.; Dolbier Jr, W. R.; Laumond, G.; Aubertin, A. J. Fluor. Chem., 2005, 126, 533-540.

14. Khabnadideh, S.; Rezaci, Z.; Khalafi, N.A.; Motazedian, M.H.; Eskandari, M. DARU., 2007, 15, 17-20.

15. Rezaei, Z.; Khabnadideh,S.; Zomorodian, K.; Pakshir, K.; Kashi, G.; Sanagoei, N.; Gholami,
S. Arch. Pharm. Chem. Life Sci., 2011, 344, 658-665.

16. Che, H.; Tuyen, T.N.; Kim, H.P.; Park, H. Bioorg. Med. Chem. Lett., 2010, 20, 40354037.

17. Ren, J.S.; Nichols, C.; Bird, L.E.; Fujiwara, T.; Sugimoto, H.; Stuart, D.I. J. Biol. Chem., 2000, 275, 14316-14320.

18. Kapoor, V.K.; Chadha, R.; Venisetty, P.K.; Prasanth, S. J. Sci. Ind. Res., 2003, 62, 659665.

19. Zhang, M.; Ding, Y.; Qin, K. X.; Xu, Z.G.;Lan, H. T.; Yang, D. L.; Yi, C. Mol. Diver., 2019, 1-8.

20. Kitbunnadaj, R.; Zuiderveld, O.P.; Christophe, B.; Hulscher, S.; Menge, W.M.; Gelens, E.; Snip, E.; Bakker, R.A.; Celanire, S.; Gillard, M. J. Med. Chem., 2004, 47, 2414-2417.

21. Hille, U.E.;Zimmer, C.; Vock, C.A.; Hartmann, R.W. ACS Med. Chem. Lett., 2011, 2, 2-6.

22. Zhang, H.Z.; Gan, L.L.; Wang, H.; Zhou, C.H. Mini Rev. Med. Chem., 2017, 7, 122-166.

23. Nami, S.; Aghebati-Maleki, A.; Morovati, H.; Aghebati-Maleki, L. Biomed. Pharmacother., 2019, 110, 857-868.

24. Popova, E.A.; Protas, A.V.; Trifonov, R.E. Anti-Cancer. Agents. Med. Chem., 2017, 17, 1856-1868.

25. Maria Dorathi Anu, M.; Jayanthi, M.; Damodar Kumar, S.; Raja, S.; Thirunavukkarasu, S.V. Int. J. ChemTech Res., 2013, 5, 1982-1990.

26. Rajasekaran, A.; Thampi, P.P. Eur. J. Med. Chem., 2004, 39, 273-279.

27. Arulmuruggan, S.; Kavitha, H.P. Acta. Pharm., 2013, 63, 253-264.

28. Praveena, C.H.L.; Rani, V.S.; Spoorthy, Y.N.; Ravindranath, L.K. J. Chem. Pharm. Res., 2013, 5, 280-292.

29. Rajasekaran, A.; Thampi, P.P. Acta. Pharm. Tur., 2003, 45, 235-240.

30. Ibrahim, F.; Nassar, Saad, R.; Atta-Allah, Abdel-Sattar, S.; Elgazwy, H. J. Enzyme. Inhib. Med. Chem., 2015, 30, 396-405. 